\title{
Application of Whiteheadian Creativity to Corporate Creativity: A Five Cs Creativity Model
}

\author{
Hong Y. Park \\ Professor of Economics \\ College of Business and Management \\ Saginaw Valley State University \\ University Center, MI 48710 \\ Email: hyp@svsu.edu \\ Il-Hyung Cho \\ Associate Professor of Computer Science \\ Department of Computer Science \\ Saginaw Valley State University \\ University Center, MI 48710 \\ Email: icho@svsu.edu \\ Sonia Park \\ Executive Consulting \\ New York, NY 11215 \\ Email: sonia.park@gmail.com \\ Geon-Cheol Shin \\ Professor of Marketing \\ School of Business \\ Kyung Hee University \\ Seoul, South Korea \\ Email: gcshin@khu.ac.kr
}

Professor Hong Y. Park received the Korea Foundation Field Research Fellowship Grant (KF Ref: 1022000-003867) and SVSU sabbatical leave in 2016 for this research and he acknowledges the Korea Foundation Field Research Fellowship Grant. He was benefited from extensive discussions on Whitehead's creativity with Professors Robert Mesle and Young Whan Oh. Authors are responsible for all remaining errors in the paper. 


\title{
Application of Whiteheadian Creativity to Corporate Creativity: A Five Cs Creativity Model
}

\begin{abstract}
Creativity is an important subject in business management, economics, psychology, sociology and philosophy, fields that deal with creating and identifying new ideas. Each of these disciplines uses a discipline-specific language and theoretical framework. The entrepreneur applies these new ideas to innovation in products, services, organizations and markets. Obviously, studies on creativity have a long history and many scholars have tried to understand the nature of creativity. Prominent philosopher Whitehead points out that creativity is the actualization of possibilities. He states that creative imagination is important for creativity, because creative imagination fosters creatives to connect seemingly unrelated actualities (connectivity) and combine known actualities (combination). Whitehead argues that creatives are more creative when they can pursue their own interests. We derive 3Cs from Whitehead's creative imagination and freedom to choose: Connectivity, combination and choice. Everything is interdependent in Whitehead's reality; thus, creativity is a social act. Scholars in other fields such as cognitive social psychology point out that human creativity arises from activities that take place in a social context, in which interactions among stakeholders and shared artifacts are important contributors to the process of creativity. Activities of stakeholders require a creative structure as an enabler; creative structure deals with coordination and collaboration, which represent $2 \mathrm{Cs}$ in our model. Thus we propose a five Cs creativity model, deriving $3 \mathrm{Cs}$ from creative imagination and $2 \mathrm{Cs}$ from creative structure. We apply the model to creative corporations.
\end{abstract}

Key words: creativity, five C's creativity model, knowledge, corporate entrepreneurship, creative industry practices.

\section{Introduction}

Creativity is the most commonly used English word in the news media and everyday conversations in Britain, according to Halewood (2014). Conversation on creativity is not unique in Britain, as it has become universal phenomenon. This is not accidental. The reason for the emphasis on creativity is the fact that creativity is the raw material of innovation (Lombardo and Roddy, 2010). There may be an even more fundamental reason underlining this phenomenon. Whitehead $(1929,1978)$ posits that creativity is the ultimate reality in the universe, the way in which individuals, organizations, nations and the universe actualize their possibilities. It is, therefore, natural that individuals, organizations and nations in the world engage in the creative process and become part of this universe. Understanding creativity is an important first step for applying creativity to corporate creativity and corporate entrepreneurship. 
Creativity in an organization can be studied from individual and organizational perspectives. Whitehead $(1929,1978)$ points out that creativity stems from the creative imagination of an individual. A creative person starts from the ground of a particular observation and then takes a flight in the thin air of imaginative generalization. Creative imagination may connect seemingly unrelated actualities and/or combine known actualities. Creatives rationalize creative imagination by observing actualities. Whitehead also argues that freedom to choose helps creatives imagine freely and choose from pure potential. Whiteheadian creativity is a process of many becoming unity.

Creativity can also be studied from organizational perspectives. Creative organizations design creative structures, which coordinate creative activities and create conducive environments for internal and external collaboration among creatives. Scholars in sociology (Bourdieu, 1977; Coleman, 1986; Giddens, 1979) study the social structures which enable as well as constrain agents. Scholars in phycology (Gibson, 1977) deal with physical structures, which create contexts for creatives to change behaviors. For example, The Apple Company's new campus was built to facilitate discussions among employees. The building is round, with whiteboards installed on the walls so that employees can write ideas on the boards at the moment of sparking new ideas. This practice captures Whitehead's $(1929,1978)$ thinking on the ancient doctrine that "no one crosses the same river twice":

No thinker thinks twice; and, to put the matter more generally, no subject experiences twice. This is what Locke ought to have meant by his doctrine of time as a "perpetual perishing." (Whitehead, 1929, 1978, p. 29)

The Apple Company's practice is to post ideas as employees experience them, because no one experiences twice. The $3 \mathrm{M}$ company is likewise known for a physical building which is constructed to encourage creatives to think creatively and to have a quiet time alone for creative imagination.

Creativity is an important source of corporate entrepreneurship. Holcombe (2003) argues that entrepreneurship discovers the stock of entrepreneurial opportunities and becomes the engine of economic growth. Creativity is thus an important source of corporate entrepreneurial 
opportunity. Deeper understanding of the nature of creativity can generate more stocks of corporate entrepreneurial opportunities, as corporate entrepreneurs actively pursue creativity by themselves and/or encourage creativity of organizational members.

Creativity, corporate entrepreneurship and competence building are crucial sources for competitive advantages of the firm (Foss, 1999; Schiuma, 2009). Casson (2014) urges researchers to make greater use of formal models and give greater attention to cognition and information processing. However, there is a paucity of studies on cognition such as creativity and its application to entrepreneurship (Foss and Mahnke, 2000; Kirzner, 1999). Therefore, to fill the gap, this paper investigates the role of creativity in corporate entrepreneurship. The study also attempts to bridge the gap between abstract theory and descriptive empiricism by applying creativity model to creative corporations.

The paper is organized as follows: Section two discusses Whiteheadian concepts of creativity. Section three examines physical and social structures of creativity. Section four proposes a five Cs theory of creativity, then section five analyzes creative corporations from the five Cs model. Section six discusses the five Cs creativity model and its application to corporate creativity. Section seven concludes the paper.

\section{Creativity}

Creativity in our daily conversation is about new ideas. Boden (1998) points out that creativity is a fundamental feature of human intelligence and it is not a special "faculty", nor a psychological property of confined to a tiny elite. For Boden, a creative idea is one which is novel, surprising, and valuable (interesting, useful, beautiful...). "Novel" has two importantly different senses: novel with respect to the mind of individual concerned (P-creativity) or to the whole history (H-creativity) where $\mathrm{P}$ represents for psychological and $\mathrm{H}$ for historical. Boden (1998) indicates that the three main types of creativity, involving different ways of generating the novel ideas: 1) novel combinations of familiar ideas called combinational creativity, 2) exploratory creativity which involves the generation of novel ideas by the exploration of structured conceptual space, and 3) and transformational 
creativity which involves transformation of some dimension the space. She argues that explorational creativity and transformational creativity are a matter of degree. The transformational creativity is a more radical novelty.

Multiple academic disciplines have studied the nature of creativity. We discuss the nature of creativity and propose to build an integrative theoretical model by connecting concepts of creativity from philosophy, cognitive psychology and sociology. Philosopher Whitehead $(1929,1978)$ offers basic foundations for creativity. Psychologist Gibson (1977) points out that affordances change behaviors of animals, including human beings. Sawyer and DeZutter (2009) stress the importance of groups in creativity. Sociologist Bourdue's (1977) and Giddens' (1979) structure is akin to Gibson's physical affordances on human behavior. We will discuss these concepts in this section and section three to provide a deeper understanding of theories on creativity from different disciplines. We will then present our integrative model, which includes factors from these diverse disciplines.

\subsection{Whiteheadian creativity}

Numerous scholars have studied Whiteheadian creativity based on his book, Process and Reality $(1929,1978)$. Hartshorn and Peden (1981) point out that Whitehead has proposed to help solve three major philosophical problems: (1) the many and one perspective, (2) the issue of efficient and final causes, (3) the problem of permanence and change. These three major problems capture the essence of Whitehead's creativity.

First, the issue of "many and one" is about two aspects of the universe. One includes a factor of unity, involving the connectivity of things. The other equal fundamental is the factor of multiplicity. According to Hartshorne and Peden (1981), there are many actualities. Description of the unity requires the many actualities. For Whitehead, the summation of many into the one, and the derivation of the importance of unity in purpose and unifying purpose from many, involves the notion of disorder, of conflict, of frustration. For example, members (many) in an organization experience disorder, conflict and frustration in deriving unity in purpose for the organization to 
establish strategic planning. Disorder, conflict and frustration are primary aspects of the universe and creativity. Therefore, we should value the process of many and one. Shaviro's (2009) integration of many and one: there are many actualities and the process of the many becoming the unity involves the notion of disorder, conflict and frustration. We observe that deriving a consensus from many people in the organization generates complexity, emergence and frustration. Shaviro (2009) points out that for Whitehead, every achievement of unity is something that has never existed before: something different, something radically new and different from any entity in the many which it unifies. This many and one is about a combination of many into one. Stenger (2011) draws an example from a judge's decision. The judge asks relevant questions from many witnesses and then decides. The decision of unity (synthesis) bear a new consequence (novelty). This novelty becomes new data. She points out that Whitehead's process and reality $(1929,1978)$ offers a "new conception of the world," the master themes of which are complexity, emergence, self-organization, and so on.

Secondly, the issue of efficient and final cause is about the nature of efficient and final causalities and relationships between them. Whitehead $(1929,1978)$ argues that actualities of the past are reasons (efficient cause) for events. According to Griffin (1988) a prehended event as the cause and prehending experience as the effect implies that the cause entered into the effect. "This passage of the cause into the effect is the cumulative character of time. The irreversibility of time depends on character" (PR, 237). Griffin (1988) points out that a positive relationship can exist between efficient and final causation. According to Shaviro (2009), final cause in Whitehead is always at work, alongside the efficient (mechanistic or physical) cause and supervenes upon the efficient cause. For Whitehead, creativity is the basic force of the universe. Creativity involves selfcausation, causal efficacy and final cause. Self-causation and final causation are interior causes and efficient cause is an exterior cause (Griffin, 1988). The Natural Sciences primarily focus on discovering efficient causes; scientists conduct controlled experiments to discover efficient causes. Self-cause is the self-preservation of actuality. Witehead's causality is forward causality, which 
implies that the past causes the present, but the present does not cause the past. The future will not cause the present because the future is not actualized yet. The actual entity is the only cause in the process of actualization. The present causes the future and causality is cumulative. The forward causality in process philosophy is applied to causality in econometrics, where scholars employ lagged independent and dependent variables in their causality test model.

Whitehead states that whatever happens must be related to reasons. Reasons are causal efficacy. Physical efficacy is about past occasions, and creativity connects them. Mesle (2008) explains connectivity as each actual entity creating itself out of past actualities: "Each actual entity must reach out and grasp those past actual entities, draw them in, and create itself out of them" (Mesle, 2008, p. 98). For Whitehead $(1929,1978)$, the actual world is a process and the process are the becoming of actual entities. Thus, actual entities are creatures, also termed "actual occasions" (PR. p. 22). Whitehead's principle of process (PR, p. 23) is relevant here. This principle states that "how an actual entity becomes constitutes what that actual entity is." The attributes of novel being (creatures or actual entities) depend on how that actual entity became. For instance, an actual entity selects eternal objects and define the final cause (aim) in the process of becoming, and definiteness of the final cause determine the attributes of the novel actuality created by this creativity process. The definiteness involves physical cause. The principle of process constitutes the nature of creatures. For Whitehead, connections are important because they make creativity possible (Rosenblum, 2017). Rosenblum (2017) points out that connectivity for Whitehead is one's ability to relate to the world. According to Rosenblum, "the more ability one has to relate to the world, the more creative one is. Thus, the creative person should participate and engage with the world" (p. 41). Deeper understanding of the world in physical and social sciences enables us to become more creative.

Final cause is about the value and purpose of an actuality. Mesle (2008) points out that selfcreativity requires some aim, some goal. Teleology and purposefulness play an important role in humans and in human organizations. Teleology in Whitehead is an ideal direction for creative 
advance. The teleology of the universe is directed to the production of beauty (Whitehead, 1933, p. 265). Whitehead proposes beauty as an ideal to be pursued (Shaviro, 2009). For Whitehead (1933), beauty is a wider, and more fundamental, notion than truth. The reason that Whitehead gives priority to beauty over truth concerns the relations of appearance to reality and the notion of conformation to reality, which in the case of truth is narrower than in the case of beauty. Whitehead (1933) elaborates his arguments:

Beauty is the internal conformation of the various items of experience with each other, for the production of maximum effectiveness. Beauty thus concerns the inter-relations of the various components of Reality, and also the inter-relations of the various components of Appearance, and also the relations of Appearance to Reality. Thus any part of experience can be beautiful. The teleology of the Universe is directed to the production of Beauty. (Whitehead, 1933, p. 265)

It is requisite for creativity to be maximum effective that the internal conformation of the various experiences, the inter-relations of various components and the relations of appearance to reality need to be harmonized. Beauty for Whitehead is harmony and proportion. Harmony among various components, various fields, and people-- harmony in everything--is an ideal to be pursued for the effectiveness in creativity. Even current global conflicts stemming from extremes might be mitigated by adopting his ideal of beauty (harmony and proportion). Extreme income inequality today may cause instabilities in society and retard economic growth; it can lead to reduction in consumption and result in low investment as well. According to Wallack (1980), Whitehead adds value and purpose to the materialist conception of nature. Materialism accepts physical causation (external causation) only. Whitehead's addition of value and purpose to nature can be envisaged from his integration of mental and physical poles. Whitehead (1933) expands the conception of teleology by espousing the value of civilization as a certain ideal for life on this earth: The ideal concerns both the individual human being and societies of men. He puts forward a general definition of civilization: that a civilized society is exhibiting the five qualities of truth, beauty, adventure, art, peace. Whitehead's notion of adventure is relevant to innovation and new product development in business. 
Efficient causes (causal efficacy) are actualized entities (many). Each actual entity selects eternal objects (pure potentials, ideas, theories) and actualizes them in the creativity process. According to Whitehead selected eternal objects ingress to the process of creativity. Not all eternal objects are selected in the process. The final cause (vision) is teleology (aim), which would affect the choice on the type of eternal objects (possibilities). The final cause (vision) can provide a guiding judgment for choices in change and novelty. Final cause defines the attributes of novelty because it is an ideal that the actual entity is pursuing. Whitehead $(1929,1978)$ states that "definition is the soul of actuality: the attainment of a peculiar definiteness is the final cause which animates a particular process" (p. 223). The attainment of definiteness implies that entities understand physical causes of definiteness. Therefore, there are connections between efficient cause and final cause (Griffin, 1988). The attributes of actualized entities are determined by the final cause and the principle of process. Here, actual entities, the most important part of Whitehead's categories of existence, are everything actual in the world (i.e., human beings, trees, rocks, planets).

Thirdly, the problem of permanence and change involves the first two problems and also involves two additional aspects in Whitehead. The first aspect is about the dominant Western philosophy, the "subject-predicate forms of thought" (Whitehead, 1929,1978). In traditional Western philosophy, the subject stays the same (permanence) and predicates change. For example, a pencil is yellow, white and green, short, long, etc. The pencil is not changing, and characteristics of the pencil are accidental. Whitehead abandons this subject-predicate form of thought and replaces morphological description with a description of dynamic process. Whitehead contrasts permanence and flux; he proposes permanence to analyze flux; eternal objects determine the characteristics of flux. Mesle (2008) offers the case of our body. If we took away all the parts of body, there would simply be nothing left. The body simply is all of those parts together, changing as its parts change. We may also draw the firm as another example. The firm is abstract, and nothing other than all of its actual people. If we take away all the people, there is no firm. The firm is all of the people together. Therefore, employees in the firm are the most important factor in firm performance. These 
examples also illustrate the change from macro prudential as well as micro prudential. Change can come from the whole as well as from parts.

\subsection{Creative imagination}

Whitehead $(1929,1978)$ argues that free imagination, controlled by the requirements of coherence and logic, plays a very important role in creativity when we seek larger generalities in philosophy. He uses an analogy to the flight of a plane for creative imagination in discovery:

The true method of discovery is like the flight of an aeroplane. It starts from the ground of particular observation; it makes a flight in the thin air of imaginative generalization; and it lands for renewed observation rendered acute by rational interpretation. The reason for the success of this method of imaginative rationalization is that, when the method of difference fails, factors which are constantly present may yet be observed under the influence of imaginative thought. Such a thought supplies the differences which the direct observation lacks. It can even play with inconsistency; and can thus throw light on the consistent, and persistent, elements in experience by comparison with what in imagination is inconsistent with them (p. 5).

The firms and all organizations are entities in the universe and are a part of the universe which is becoming. Therefore, creativity can be applicable to the discovery of corporate entrepreneurial opportunities. Since theories require imagination (Casson, 1998), the influence of imaginative thought is critical in constructing a creativity theory in corporate entrepreneurship. Schumpeter's (1934) fragments of entrepreneurs' imagination matter here. Potential entrepreneurs start from the ground of particular observation on corporate entrepreneurial opportunities, make a flight of imaginative generalization, and land for renewed observation rendered by rational interpretation. This method can throw light on whether imagination is inconsistent with observation or reality. The entrepreneurial theory based on imagination needs to be coherent and logical and to be examined by the applicability of its results beyond the restricted observation, as we can then construct generalization in the market for corporate entrepreneurs. We believe that Whitehead's choice of words, imaginative rationalization, is a crucially important point. He states that "rationalism is an adventure in the clarification of thought, progressive and never final" (Process and Reality, 
1929,1978, p. 9). We continue to clarify our thought on creativity in economics and management and make progressive improvement.

In Whitehead's philosophy of the organism, "the ultimate is termed creativity" (PR, 7).

Whitehead $(1929,1978)$ clarifies creativity in his Process and Reality:

"Creativity" is the universal of universals characterizing ultimate matter of fact. It is that ultimate principle by which the many, which are universe disjunctively, become the one actual occasion, which is the universe conjunctively. It is in the nature of things that the many enter into complex unity .... "Creativity" is the principle of novelty. Actual occasion is a novel entity diverse from any entity in the many which it unifies. Thus creativity introduces novelty into the content of many, which are the universe disjunctively. The "creative advance" is the application of this ultimate principle of creativity to each novel situation which it originates (PR, 21).

Here, Whitehead points out that creativity is the nature of the universe and the universe consists of many actual occasions. However, Whitehead is neutral on whether creativity results in good or bad outcomes. However, Fetz (1990) argues that the creativity advance is transforming of something into something better. What do we mean by something better? Whitehead favors the fidelity to openended search for what is true, good and beautiful. Mesle (2008) points out that such a search at its best engages us continually in a relational process. Therefore, we can surmise that the ultimate criteria for innovation or judgments are goodness, truthfulness and beauty. Of course, profits are an important criterion for judgment in economics.

Creative imagination is important in Whiteheadian creativity. Whitehead's creative imagination implies that an individual connects dots, combines various known ideas and makes choices on relations with other individuals and ideas (eternal objects). New ideas and theories are choice set in Whiteheadian creativity.

\subsubsection{Creativity as the fundamental of the universe}

According to Shaviro $(2009)$, Whitehead $(1929,1978)$ and German Philosopher Heidegger (1959) ask two important questions in philosophy. Heidegger (1959) asks the question of being: "Why is there something, rather than nothing?" Heidegger's question is about the ontology or being of the firm in 
economics. Why is there a firm rather than a market? This question has been a question in theories of the firm because it deals with the origin, foundation and boundary of the firm. The transaction cost theory of the firm (Coase, 1937; Williamson, 1975, 1985) further clarifies market and hierarchical organization.

Whitehead $(1929,1978)$ asks the question of becoming: "How is it that there is always something new?" For Whitehead, creativity is the fundamental force of the universe. According to Shaviro (2009), Whitehead breaks the tradition of philosophy from its orientation to the past toward the future. The new is the fundamental concept, and the production of novelty is an ultimate metaphysical principle; emergence and creativity are oriented toward the future. Shaviro's (2009) interpretation on Whitehead's futurity describes the nature of Whitehead's future orientation:

For, just as the past remains active within the present by means of the "vector transmission" of efficient causality, so the future is already latent within the present, thanks to the "multiplicity of pure potentiality" (Whitehead, PR, p. 164) that can be taken up by the living actual occasion. "The past is a nexus of actualities" (Whitehead, PR, p.214); it is still actual, still a force in the present, because it is reproduced as a "datum," physically prehended by each new actual occasion. On the other hand, the future is available, without having yet been actually determined: it takes the form of eternal objects, or "pure potential" that may be conceptually prehended (or not) by new actual occasion. Whitehead says, therefore, that "the future is merely real, without being actual." (Shaviro, 2009, p. 97)

The vector of transmission of efficient causality remains within the present. We need to discover efficient causes to understand current events. Whitehead's futurity implies that the future is available now as possibilities. Deeper understanding of the vector transmission of efficient causality can provide foresight on the direction and forces of changing events. Whitehead (1933) also indicates that business organizations quantify the quality of change in the air. Entrepreneurs sense this feeling and quantify it for innovation. Schumpeter's (1934) entrepreneurial plans capture the same spirit of Whitehead and his entrepreneurial plans are based on "figments of our imagination." The idea of Whitehead's feeling of the quality of change in the air helps form figments of entrepreneurial imagination. 
Mesle (2008) states that Whitehead looked more deeply at the character of life as novelty. Novelty is the root of life and essential for our survival. An additional aspect of permanence is eternal object. Eternal objects (pure potentials) are permanent and remain as potentialities even if they are actualized. Potentials (possibilities) can be actualized again and again without being exhausted as they are actualized. Eternal objects or potentials (possibilities) are crucially important in understanding Whitehead's creativity.

The Whiteheadian universe consists of events and processes, and for Whitehead (1929, 1978) all events are becoming. The essence of his philosophy of the organism is creativity, and creativity is the ultimate reality. The nature of the universe is becoming. Shaviro (2009) points out that Whitehead's philosophy is grounded in events, becomings, and continual change and novelty. Whitehead's philosophy fits well to today's business buzzwords, continuous improvement or innovation. His creativity is the generality of change and becoming. We, therefore, employ his concept of creativity in this paper to explain phenomena in innovation and corporate entrepreneurship. Whitehead $(1929,1978)$ further argues that creative advance and creative imagination, key elements in creativity, can be taught. According to Fetz (1990), "creative advance is the Whiteheadian term for the totality of natural events, for the current of cosmic happenings, insofar as it is not simply reproduction, but a production of new actual entities of a higher level" ( $p$. 202), the transformation of something into something better.

\subsubsection{Nows and creativity}

Whitehead $(1929,1978)$ argues that events are constantly becoming. Griffin (2007) explains that "now" does not stand still, but always divides a different set of events into past and future. Therefore, there are infinitely many "nows" and they divide past and future. Shaviro (2008) points out that "nows" are interstices between present and future (p. 97). Nows connect the past and the future. We observe that new trees and plants pierce through the interstices in the rock, and the present as an interstice is, therefore, important in Whiteheadian creativity. The present plays as an interstice in Whiteheadian creativity. Whitehead's appetition is an appetite (desire) in the present 
and an urge towards the creative advance. The firm's appetite can be profit, value and purpose. As firms make decisions to fulfill the appetite, the future will be actualized.

Griffin (2007) further clarifies the concept of a settlement of the past and future. According to him the past is fully settled, while the future involves potentialities still to be settled. The vector transmissions of efficient causality on the past offer understanding of the settled past. He points out that the present, the "now" between past and future, is assumed to the time in which potentialities are being settled. Wallick (1980) states that "the time-span, or temporal duration, of an occasion is its present; it covers both its potentiality and its actualization" (p. 104). Wallick (1980) further points out that the epoch is the unit of Whiteheadian time, and an epoch cannot be understood as an instant; it can be a minute, hour or month, depending on what the occasions are. Therefore, Whiteheadian time is relative compared to Newtonian absolute time. Potentialities are latent in the present. Therefore, the future is available or imminent at the present as potentials (possibilities). Mesle (2008) illustrates how decisions or making choices create the future. "The future does not exist, and the future must be created. The creatures of the present must decide between many possibilities for what may happen, and their collective decisions bring the moment into being" (Mesle, 2008, p. 7). Shaviro (2009) points out that both the physical causality and the choice of eternal objects are involved in Whitehead's creativity.

We cannot ignore the physical chain of causality that is at work in a given event; but we do not want to stop there. We also "require to understand," as Whitehead says (cited in Stengers 2005, 42), the reason behind this chain of causality, the "decision" that makes of it what it is.... Whitehead warns us that such "decision cannot be construed as a causal adjunct of an actual entity. It constitutes the very meaning of actuality" (1929/1978, 43). (Shaviro 2009, p. 25)

This citation illustrates the importance of decision in creativity. Whitehead (1933) points out that "progress is founded upon the experience of discordant feelings. The social value of liberty lies in its production of discords" (p.257). Because of the created discords, the creatures of the present face crisis, confusion, frustration and chaos (Hartshorne and Peden, 1981) in making choices, and thus time is not linear. However, the produced discords are sources of creativity because discords are 
diversities because disjunctive diversity converges into conjunctive unity and novelty through interactions among entities.

Actual entities are physical causes, and eternal objects are potentials, alternatives and contingencies for becoming of actualities (Shaviro, 2009). A potential cannot be a cause because it not actual. An organization may not actualize the most valuable potential in making choices among alternatives and not tap the reservoir of possibilities. Therefore, right choices and decisions by individuals, leaders in organizations and policy makers are crucially important in creating the better future of an individual, an organization and the world. This is the nature of Whitehead's creativity and his quest for beauty which is harmony and proportion. Therefore, Whitehead's creativity and beauty can be applied to solve problems in all entities, including individuals, organizations, nations and the universe. When these entities actualize potentials, they reach self-enjoyment. Whiteheadian creativity is, therefore, not just a novel idea, but a process of becoming which can be applied to all occasions or events. Eternal objects offer choice set. The choice set in the firm can be expanded by collaborating internally and externally (see scouting in Park et al., 2015a).

\subsubsection{Creativity conditioned by environment}

Events are conditioned to change, and the conditions involve actualities and nature in Whitehead. Creativity is always found under conditions, and described as conditional (PR, 31). For Whitehead, creativity is conditioned by social environment (p. 203). Whitehead's ontological principle states that there is nothing which floats into the world from nowhere. Actual occasions are reasons. Actual entities make up Whitehead's society. He stresses that creativity is generated by self-cause, efficient cause and final cause, and argues that creativity is social. These are ideas from Whitehead's speculative philosophy and we can apply them in economics and management. If we apply these causes to a business firm's change and innovation, the firm is a continuing and ongoing entity. A firm's change, innovation and creativity are accidents of environments. The high velocity of changes in today's business and economic environments cause business firms to be creative. The business 
environment consists of new technologies, regulations and markets such as suppliers, customers and competitors (Park et al., 2018).

\subsubsection{Whiteheadian creativity process and causality}

The Whiteheadian creativity process discussed above can be summarized in Figure 1:

\section{Creativity Process}

Causal Efficacy Self-Causation Satisfaction

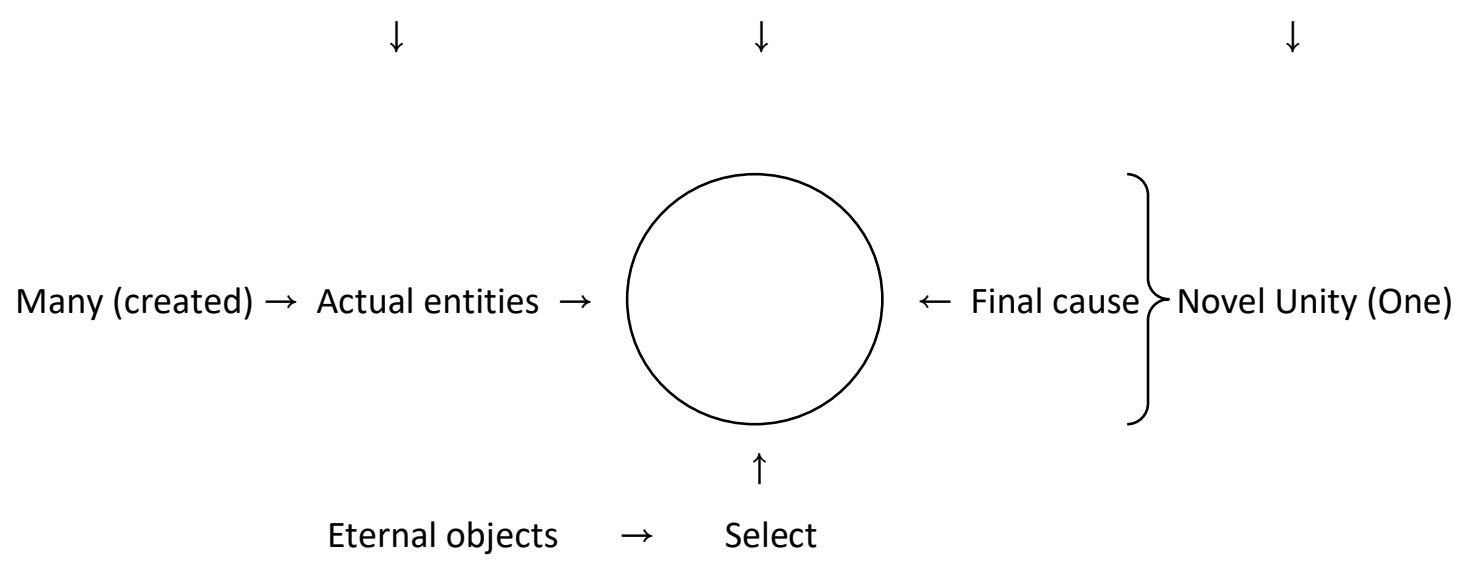

Figure 1: Creativity Process

As stated before, the Whiteheadian creativity process explains how the many become a novel unity. He uses the term "satisfaction" when the many become the one. Many are concrescing and relating to each other in the creativity process. This graphical presentation summarizes three causal links in the Whiteheadian creativity process.

First, Whitehead (1929/1978) points out that "an actual entity feels as it does feel in order to be the actual entity which it is (PR. P. 222). He then argues that an actual entity satisfies Spinoza's self-causation (causa sui). According to Parashkevova (2015) when philosophers refer to a thing, an action, or a process as self-caused, they mean at least one of two things. The thing is self-cause and/ or it logically self-caused. For Whitehead, the self-cause implies that nothing comes from nothing 
and the subject completes itself during the process of concrescence by a self-criticism of its own incomplete phases (Whitehead 1929/1978. p. 244). Each actual occasion defines its own actual world from which it originates (PR. p. 210). The firm's employees come from their own past and have innate drives (appetitive) to be creative (self-cause). This ontological principle in Whitehead elucidates the existence of the firm explains its own existence and self-change for the better.

Second, physical causality indicates that the past actualities are reasons for whatever happens. Employees in the firm also interact with each other, competitors, suppliers, customers, science communities, regulators and nature. Interactions with these entities imply that employees in the firm affect each other. These entities are interrelated (principle of relativity). Firms use raw materials, labor, capital and technology and discharge carbon dioxide into the atmosphere as they produce products. Air and water pollutions are examples of the firm's interactions with nature. Physical interactions among these inputs elicit something new.

Third, people in the firm makes change to increase profits (final cause) or to supply what customers want. According to Shaviro (2009) Whitehead's ideal for final cause (teleology) is beauty and for him the beautiful is about harmony and proportion (Shaviro, p. 152). It is said that Apple's founder, Steve Jobs stressed the importance of beauty in product design and simplicity of technology (Issacson, 2011). He worked with designers and engineers to bring about beautiful and easy-to-use product. Vision of the firm is the final cause for Whitehead and firm's visions established by organizational members or leaders provide guides for resource allocation decisions and these decisions help create new products and services. Therefore, the principle of process and final cause are working together in new product development. In other words, novelty is caused by the principle of creativity process. We now examine how human organizations design social and physical structures to elicit creativity in their organizations.

We now examine how human organizations design social and physical structures to elicit creativity in their organizations. 


\section{Creativity in Psychology and Sociology}

As Gibson's (1977) affordances are akin to structures in sociology, we discuss them together. Gibson (1977) argues that the environment constrains what the animal can do within its limits, and how the human animal can alter the affordances of environment. Structure in sociology (Giddens, 1979; Bourdieu, 1977, Coleman, 1986) refers to constraints and enabling; it is like Plato's receptacle (Malvestiti, 2011). Glăveanu $(2012,2014)$ argues that creative action is distributed among multiple actors, creations, places and times. We may develop a creativity model incorporating social environment, affordances, structure and distributed creativity. Operationalizing Whitehead's creative imagination and creative advance may lay foundations for the creative economy; we may bring additional perspectives from psychology and sociology.

\section{1 Creativity and physical structure in psychology}

Psychology has provided several valuable perspectives on creativity. First, Gibson's (1977) affordances of the environment are what it offers the animal, what it provides or furnishes, either for good or ill. Physical affordances of air and water enable the animal to breathe and swim. Firms likewise construct physical structures to enable their creative employees to be more creative. For example, The Apple Company's new facility is designed to generate more social interactions or engagement among employees, because interactions have been found to be an important factor for creativity. Whitehead $(1929,1978)$ concurs that creativity is conditioned by physical environment (efficient cause); affordances are equivalent to factors of efficient causes. Water flows in a river and banks constrain the flow of the river, but it can overflow by flood which relieves constraint, becoming creative or changing. We often state that we can't cross the same water twice. This implies that the actuality continues to change.

Secondly, distributed creativity has become prominent in creativity discussions in psychology. Scholars in distributed creativity stress the importance of groups (Sawyer and DeZutter, 2012). They define "distributed creativity to refer to situations where collaborating groups of 
individuals collectively generate a shared product" (Sawyer and DeZutter, 2012, p. 82). According to Glăveanu (2012 and 2014), creativity is distributed among people, objects and places. He argues that it is important to recognize that the creating person does not create in isolation, that creative action extends into the world of other people. Therefore, group creativity or creation as co-creation needs collaboration among creatives. Glăveanu (2014) indicates that social interaction has become an emergent process in co-creation, as collaboration requires both structure and openness for creative outcomes to be generated. Brainstorming and ideation have been the most prevalent such structures in psychology. Park et al. $(2012,2015 a)$ illustrates how ideation/idea central facilitates the new idea generation.

\subsection{Creativity and social structure in sociology}

Structure in sociology has emerged as an important field of research in recent years (Bourdeu, 1977; Giddens, 1979, Coleman, 1986). For Whitehead $(1929,1978)$, creativity is always social, involving many creatives who interact and relate each other. Individuals choose collaborating groups and relationship. Structure in sociology and management is akin to the concept of physical affordance in psychology. Both structure in sociology and physical affordance in psychology deal with behaviors of human beings facing constraints in terms of individuals and groups. Structure in sociology involves the relationship between the structure and agents. Giddens $(1979,1984)$ refers to structures as rules and resources. He regards the rule of social interaction as "techniques or generalizable procedures applied in the enactment/reproductions of social practices" (1984, p.21). He considers three dimensions of social structure in his structuration theory: signification, legitimation, and domination. (For detailed discussions on knowledge creation structures, readers may refer to Park's et al. (2015a) article on firms' knowledge creation structures.)

Structures can be both social and physical. Giddens' structure is social, whereas 3M Company, Pixar and Apple's new buildings and campuses are built to be conducive for creativity in physical structures. Physical structure is an affordance for Gibson (1977). Structure involves an antinomy: It enacts and enables human agents on the one aspect and constrains actions of the agent 
on the other (Bourdue, 1977, 1979; Weick, 1977, 1979). Addressing this antinomy requires careful design in structure, and designers of the structure include elements of reflexivity (Park et al., 2015a). For example, The Pixar Company conducts postmortems to find out what went well and what went wrong in a new production of an animation picture (Catmull, 2008). This practice continues to improve the structure and avoid the same mistakes in the future. It can also mitigate the problems in antinomy of the structure. Amabile (1988) found that "freedom was the most prominent environmental promoter of creativity, and constraint was the second most prominent environmental inhibitor of creativity" (p. 148). She argues that structure requires a delicate balance between freedom and constraint. We have discussed what social and psychological conditions are favorable to creativity. The organization needs to provide those conditions when designing the structure for creativity.

\section{3 Creatives and creative structures}

The research question in this study is what the relationships between creatives and creative structures are. Structure and agent in sociology is about subject and object in Whitehead. The study of the social is the study of subjects and objects (Halewood,and Michael, 2008). We get to choose subjects and objects. Creatives are subjects and structures are objects. The structure in sociology is a social structure (Giddens, 1979, 1984), whereas structure in psychology (Gibson, 1977) is a physical structure (physical affordance). Halewood and Michael (2008) states that structures cause different kinds of agent (subjects) and agents cause different kinds of structures. Bourdue (1977) argues that structures are enabling and constraining agents. His antinomy of the structure has been addressed by making changes based on the reflexivity (see detailed discussions in Park et al., 2015a).

Whitehead (1927) makes a similar point according to Weber (2016) who points out an important point on Whitehead's process: "Actual processes are never twice the same because they depend on their environment and because this environment is always changing" (Weber, 2016, p. 359). Designing a proper context-specific structure is necessary in the process of creativity. For Whitehead, the structure needs to be conducive for interactions among creatives and conditional to 
environmental changes and social relationship. It is possible that creatives may create different relationships each time they are involved in creative events under the same structure, as Weber (2016) points out. Based on these ideas, we construct a creativity model combining creative thought proposed in philosophy, psychology and sociology.

\section{Creativity Model}

As discussed above, creativity in Whitehead originates from creative imagination. For Whitehead $(1929,1978)$ creative imagination stems from physical conditions, and corporeal experiences are sources of mental experience. His primordial proposition is that creativity is conditioned on negation or destruction of given data; this negation of the given is the fundamental proposition of creativity. This point is well practiced by Toyota Company, which is known to ask customers about problems in their new products rather than just how good their products are. This has become a practice in the automobile industry. As they know what is not good, they can make changes. Wonder is the beginning of creative thinking. This proposition may be akin to the critical thinking in today's creativity discussions. Thus, we draw 3Cs from Whiteheadian creative imagination. Sociology and psychology offer factors that are requisite for the creative structure.

A creative model ought to involve creative imagination of creatives and creative organizational structure. We propose a five Cs model based on ideas from philosophy, psychology and sociology discussed above: Three Cs from the Whiteheadian creative imagination of creatives and two Cs from the creative structure in creativity. Creatives or creative individuals draw creativity from creative imagination, and the organization creates an environment for creatives to enact creativity.

\subsection{Creativity as 5 Cs}

Stengers (2008) points out that the task of philosophy, according to Whitehead (1978), is engineering relevant abstractions. A creativity model needs to engineer relevant abstractions for creativity. We engineer relevant abstractions from philosophy, psychology and sociology in 
constructing our creativity model, which is called the combination or the hybrid (Halewood and Michael, 2008). Halewood and Michael (2008) argue that "in the actual occasion of academic practice, completion or satisfaction is reached when sufficient examples are collected to establish the multiplicity manifested in the poly-ingression of eternal objects and their interplay with actual entities" (p. 51). The multiplicity in novelty emerges in the interplay of such entities and eternal objects (Halewood and Michael, 2008). We will first engineer relevant abstractions to build a theoretical model and then provide a few practical examples to support the model. For Whitehead $(1929,1978)$, creativity is actualization of possibilities (eternal objects). Perhaps, we can say that creativity is all about "C."

$\begin{array}{cll}\text { Creativity } & & \text { Combination } \\ \text { Creative structure: } & \begin{array}{l}\text { Collaboration } \\ \text { Choice }\end{array} \\ & \text { Coordination }\end{array}$

We propose that creativity in organizations can be thought of from two broad perspectives: creative imagination and creative structure. Creative imagination involves creatives, and members of an organization create a structure or affordance in the organization. We draw three Cs from Whitehead's three issues that he has proposed to answer: many and one (combination), the issue of efficient cause (connectivity) and the issue final cause (choice). The Google Company, for example, sees creativity as a way of solving problems - large and small. The ability to create is the ability to solve problems creatively. In human history, entrepreneurs have solved most of the problems that we have faced. We argue that creativity then is all about " $\mathrm{C}$ ": Combination, connectivity, Choice, Collaboration and Coordination.

This Five Cs framework is comparable to ideas in the four P's framework in Rhodes (1961) and the five A's framework in Glăveanu (2012). We draw relevant abstracts for creative imagination 
rom Whitehead and from Giddens (1979) and for creative structure from Glăveanu (2012) and Giddens (1979).

We next examine applications of this 5 Cs creativity model to U.S. corporate creativity.

\section{The Five Cs model in Industry Practices}

To examine the practices employed by the most innovative and creative firms in the $21^{\text {st }}$ century, 3M, Google and Apple, we will analyze each firm's practices to illustrate the five C's model.

\subsection{The 3M Company}

Founded in 1902, 3M launched the 15 percent program in 1948; employees could use 15 percent of their paid time to chase rainbows and hatch their own ideas. Though it seemed radical, this idea has produced many of the company's best-selling products and is now the key to 3M's business strategy. Today 3M Company produces five thousand products with five thousand employees (Lehrer 2012), and the 15 percent time is now extended to every employee of the company. "Innovate or die" has become an ethos of the $21^{\text {st }}$ century company; $3 \mathrm{M}^{\prime}$ s practices illustrate the five C's model.

\begin{tabular}{|c|l|}
\hline Practice & \multicolumn{1}{c|}{ Description } \\
\hline Connectivity & $\begin{array}{l}\text { Creative people like to make connections among disparate but related } \\
\text { knowledge. Workers discover things or come up with ideas in their usual course } \\
\text { of work, something that may be used to solve problems by enhancing the } \\
\text { current product, streamlining the current manufacturing procedure, or even } \\
\text { creating new products. Previously, workers often did not pursue their } \\
\text { discoveries or ideas because they lacked time, or the ideas or discoveries were } \\
\text { not directly related to their current work or might not be related to each other. } \\
\text { Ideas often came and went, and might reappear again, but seldom led to } \\
\text { concrete ideas that could be used to solve problems; if they languished, they } \\
\text { might eventually be forgotten and never bear fruit. With the 15 percent time, } \\
\text { creative workers will bring out their findings and discuss the relevance to their } \\
\text { current work by connecting their findings to their work. }\end{array}$ \\
\hline Combination & $\begin{array}{l}\text { The allocated fifteen percent of an employee's time is not just for scientists, but } \\
\text { for every employee in 3M. This allows people with diverse education } \\
\text { backgrounds, gender, and specialties to work together to combine their ideas for } \\
\text { innovation. 3M has an annual gathering with hundreds of employees from } \\
\text { dozens of divisions presenting their ideas and discoveries in a poster session. } \\
\text { They share feedback, suggestions, and often find future collaborators who many }\end{array}$ \\
\hline
\end{tabular}




\begin{tabular}{|l|l|}
\hline Choice & $\begin{array}{l}\text { times bring in fresh ideas. Sometimes, they do not get appropriate feedback } \\
\text { right away; one worker held an idea for 15 years with no productive feedback, } \\
\text { then 15 years later got different feedback that eventually led to a successful } \\
\text { product. Many of the current 3M products stem from the activities during 15 } \\
\text { percent time. }\end{array}$ \\
\hline Collaboration & $\begin{array}{l}\text { Workers at 3M are not constrained to work on any specific products or projects } \\
\text { in their 15 percent time, and 3M essentially offers freedom to employees so that } \\
\text { they can exercise their creative and innovative idea, which further softens } \\
\text { boundaries between where ideas come from and how they take root. }\end{array}$ \\
\hline Coordination & $\begin{array}{l}\text { Most 3M products from 15 percent time have come from group work. The } \\
\text { annual poster session works as a vehicle to connect people with inspiring and } \\
\text { groundbreaking ideas. }\end{array}$ \\
\hline $\begin{array}{l}\text { 3M did not simply offer 15 percent time to all employees to freely exercise their } \\
\text { mental curiosity. Many good ideas remain locked in one's head and left } \\
\text { unexploited because people think their ideas are not good enough, or they feel } \\
\text { shy about their findings or discoveries. When 3M organized poster sessions to } \\
\text { guide and coordinate interactions among employees, this encouraged } \\
\text { employees to come out and take action, providing an environment for } \\
\text { collaboration and connecting the dots. The company's physical facilities are like } \\
\text { college campuses and offer an atmosphere for creatives to imagine or daydream } \\
\text { (Lehrer, 2012). 3M creates a structure for employees to interact, share and } \\
\text { collaborate. }\end{array}$ \\
\hline
\end{tabular}

\subsection{The Google Company}

Since its IPO in 2004, Google has grown beyond a simple search engine company, and is now considered one of the most innovating and non-conventional IT companies in the world. Google has been continuously innovating by encouraging interactions between employees and tapping their creative ideas to percolate up. Google also has a 20 percent time policy similar to 3M's 15 percent program, allowing workers to spend $20 \%$ of their work week on projects that most interest them.

\begin{tabular}{|c|l|}
\hline \multicolumn{1}{|c|}{ Practice } & \multicolumn{1}{c|}{ Description } \\
\hline Connectivity & $\begin{array}{l}\text { Google provides multiple channels to encourage interactions among employees } \\
\text { within and across teams. The channels include Google Café, direct emails to any } \\
\text { of the company's leaders, Google Moderators, and Google+ conversations, } \\
\text { among others. These channels allow people to ask questions, and post ideas or } \\
\text { suggestions. Other people can discover these questions, ideas, and suggestions, } \\
\text { and organize meetings or events to discuss them, and possibly work on them in } \\
\text { their 20\% time. }\end{array}$ \\
\hline
\end{tabular}




\begin{tabular}{|c|c|}
\hline Combination & $\begin{array}{l}\text { Google values different ideas from different people, and the } 20 \text { percent time } \\
\text { policy includes everybody working for the company. Google Café is designed to } \\
\text { encourage not only employees within teams, but across teams, to meet with } \\
\text { diverse employees and to spark conversations about their work and ideas. } \\
\text { Google introduced the } 70 / 20 / 10 \text { rule, which allows employees to devote } 70 \\
\text { percent of their time to their core business, } 20 \text { percent on related projects, and } \\
10 \text { percent to learning new skills and working on unrelated projects. This model } \\
\text { allows employees to keep their focus on core needs, while encouraging them to } \\
\text { explore new and related areas with other employees. }\end{array}$ \\
\hline Choice & $\begin{array}{l}\text { According to the } 70 / 20 / 10 \text { rule, } 10 \text { percent of the projects are unrelated to the } \\
\text { current projects, and employees have freedom to choose their own projects. } \\
\text { Google employees can spend their } 20 \% \text { of time on the } 10 \% \text { unrelated projects. } \\
\text { Some of those projects can become their } 70 \% \text { projects in the future. These } \\
\text { freedoms of choice have led to innovative ideas like driverless cars, Google Glass, } \\
\text { Google Maps, and Google Docs. }\end{array}$ \\
\hline Collaboration & $\begin{array}{l}\text { Google Café is designed to encourage interactions between employees within } \\
\text { and across teams. Google has a flexible work space called Google Garage, a big } \\
\text { space with lots of tables with computers, whiteboards, 3D printers, cool tools (or } \\
\text { toys), chairs, and couches, and it essentially works as a playground for Googlers } \\
\text { (Google employees). Everything in the place can be moved around and } \\
\text { reconfigured, and employees can come and join with other people to learn, } \\
\text { design, create, make, and share ideas and have fun. This kind of collaboration } \\
\text { provides an ultimate flexible and functional workspace, improves productivity, } \\
\text { and helps people work together better. }\end{array}$ \\
\hline Coordination & $\begin{array}{l}\text { Google Moderator is an innovation management tool that organizes, and } \\
\text { coordinates questions, ideas, and suggestions submitted by employees. It } \\
\text { provides management with feedback from many people, who can vote for } \\
\text { questions they think should be posed from a pool of questions submitted by } \\
\text { others or submit their own questions to be asked and voted on. The process } \\
\text { aims to ensure that every question is considered, lets the audience see others' } \\
\text { questions, and helps the moderator of a team or event address the questions } \\
\text { that the audience most cares about. }\end{array}$ \\
\hline
\end{tabular}

\subsection{The Apple and Pixar Company}

Apple is the number one innovative company in the world. Since their very first Apple Computer in 1976 and Macintosh in 1984, to the current iPod, iTunes, iPhone, iPad, and iMac, Apple has been different kinds of companies with a different view of the world, but has always delivered innovative products with elegance, style, simplicity, and beauty. Pixar, also created by Steve Jobs while he was ousted from Apple, is considered a pioneer and one of the most successful and innovative companies in 3D computer animation. Now, Apple leads the ICT business in hardware, software, and 
entertainment, and the Boston Consulting Group ranked Apple as the world's most innovative company in a report it issued in December 2015. While running both Apple and Pixar, Jobs was known to be more relaxed and less harsh and critical of the employees in Pixar than in Apple, but still there are many common attributes that led to the success of both companies. As Jobs was the CEO and creative leader for both Apple and Pixar, we present the creativity model using examples from both companies.

\begin{tabular}{|c|c|}
\hline Practice & Description \\
\hline Connectivity & $\begin{array}{l}\text { According to Isaacson (2011), Apple's founder, Steve Jobs, applied imagination to } \\
\text { technology and business. He was known for connecting hardware, software and } \\
\text { services, the business model of The Apple Company (Rose, 2014). Jobs preferred face- } \\
\text { to-face meetings over email, chatting, or video conference, because he believed } \\
\text { different, spontaneous, and creative ideas come from different people meeting face- } \\
\text { to-face. The Pixar building has been designed to promote unplanned encounters and } \\
\text { collaborations among people from different departments with different skill levels - } \\
\text { from software programmers to designers, marketing staff, and retail employees. Jobs } \\
\text { said, "If a building doesn't encourage that, you'll lose a lot of innovation and the magic } \\
\text { that's sparked by serendipity." }\end{array}$ \\
\hline Combination & $\begin{array}{l}\text { Creativity involves many people from different disciplines working together effectively } \\
\text { to solve a great many problems. In Pixar, Technology, combined with Art, creates } \\
\text { Magic. Jobs was always surrounded by great engineers, scientists, designers and } \\
\text { artists, but he was the one who wired them together to produce innovative products } \\
\text { that served humanity well. Under the current leadership from Tim Cook, Apple } \\
\text { promotes diverse employee backgrounds and perspectives to spark innovation and } \\
\text { create opportunities for the next generation. The most interesting, creative, and } \\
\text { innovative ideas come from these combinations of diverse perspectives. }\end{array}$ \\
\hline Choice & $\begin{array}{l}\text { In Pixar, enormous leeway decisions and control every state of idea development. In } \\
\text { Pixar, all of the stories, worlds, and characters were created internally by their } \\
\text { community of artists, not bought from outside. Without freedom to unleash their } \\
\text { creativity and ingeniousness, they may have been less successful. }\end{array}$ \\
\hline Collaboration & $\begin{array}{l}\text { In Pixar, everyone is encouraged to freely communicate with everyone. Members of } \\
\text { any department can directly approach anyone in another department to solve } \\
\text { problems, and employees share their work with peers who provide candid feedback. } \\
\text { Apple has built a new headquarters, called Apple Campus, in Cupertino, California, } \\
\text { which houses more than 13,000 employees in one building. The building is circular } \\
\text { shaped (spaceship-like) and the proximity and adjacency of different departments } \\
\text { have been considered very carefully so that people in different departments can work } \\
\text { together easily. In the middle is a } 1000 \text { seat underground auditorium for events and } \\
\text { presentations. The building also has a Café for Apple employees to discuss work in a } \\
\text { secure and private area. }\end{array}$ \\
\hline
\end{tabular}




\begin{tabular}{|l|l|}
\hline Coordination & $\begin{array}{l}\text { Apple collaborates not only within the company, but with many external companies } \\
\text { (156 companies in a } 2012 \text { study) of different sizes, including Cisco, Intel, IBM, Google, } \\
\text { and Microsoft; many Apple products are the result not only of the genius of the late } \\
\text { Steve Jobs and his A-team of engineers, but of many alliances and collaborations. }\end{array}$ \\
\hline $\begin{array}{l}\text { While many creatives in Pixar have freedom to make their own decisions and exercise } \\
\text { their creativity, it is the leaders who sort through the mass of ideas to find the ones } \\
\text { that fit into a coherent whole. In Apple, employees are often encouraged to make } \\
\text { suggestions to improve current products or to choose directions for the future. Each } \\
\text { year, Steve Jobs took his "top 100" people on a retreat and asked, "What are the 10 } \\
\text { things we should be doing next?" Many suggestions were made, but it was Steve Jobs } \\
\text { who finally determined the best three. He filtered out distractions and focused on } \\
\text { core services and products that Apple could do best. Pixar is creating an environment } \\
\text { conducive for creativity. The Pixar Company values employees and instills the idea } \\
\text { that the whole is greater than the sum of the parts, creating an environment where } \\
\text { employees respect and trust each other and provide honest feedback (Catmull, 2008). }\end{array}$ \\
\hline
\end{tabular}

These examples are supportive of the 5 Cs model. In the business world, when a firm sets an aim for a new product, the firm makes decisions to accomplish the aim. The result of decisions is the firm's new product. Efficient causes (causal efficacy) are actualized entities.

\section{Discussion}

For Whitehead, creativity is a process of becoming and creativity is the ultimate of the universe. In other words, the general pattern of the universe is creativity. Creativity is actualizing potentials and potentials can be real or pure. Real potentials are actualities and pure potentials are ideas and theories. Pure potentials are choice set to be actualized. Whitehead's process involves many and one (unity). Every achievement of unity is something that never existed before: something different, something radically new and different from any entity that in the many which it unifies (Shaviro, 2009). Stengers (2011) argues that Whitehead offers "a new conception of the world," the master themes of which are complexity, frustration, emergence, self-organization, and so on. Time unit in creativity is an epoch which can be hours, months and years. His time is relative compared to an absolute time for Newton. Time is not linear and creative advance may go through a detour. We have often experienced that a creative advance goes forward, but sometimes go backward or 
detour. Whitehead $(1929,1978)$ argues that creativity can be learned. We have, therefore, proposed a five Cs theory of creativity: Connectivity, Combination, Choice, Collaboration and Coordination and examined practices of creative firms considering our proposed five Cs theory. The ever-evolving ITCS expand connectivity and collaboration beyond the traditional boundaries of the firm and the nation, which helps organizations be creative and entrepreneurial.

Actual entities (physical causes) interact (engage) and they are also relational. Interaction and relationship in Whitehead's creativity are relevant in today's corporate creativity. As illustrated in the three cases in this paper, firms create structures for creatives to interact and build relationships. Some forces in the entity continue to inherit its past, and eternal objects are chosen or selected to become the ideal set by the entity. This is akin to the firm in which some forces are resisting changes and others are actively involved in making changes. In the firm or organization, actual entities are interacting, and they are relational. Interactions and relationships are determinants of creativity in Whitehead. Past actualities are physical causalities; contemporary entities are concrescing (growing together).

Information and communications technology (ICT) in hardware, software and services opened many entrepreneurial opportunities in the ' 90 s and those firms are highly valued today. We have examined 3M, Google and Apple/Pixar in our study. Numerous new entrepreneurial opportunities will continue to emerge in the ICT industry with development of Cloud computing and artificial intelligence (Al) as creativity connects these fields and combines numerous known ideas.

\section{Conclusion}

We proposed a five Cs creativity model and examined industry practices of creative corporations based on the model. Information and communications technology (ICT) and broad knowledge of employees expand choice set for creative firms which help the organization more creative.

Deeper understanding of Self-cause, efficient and final cause validates value of definiteness of vision in an organization. Vision determines characteristics of the creative outcomes and animate activities in creativity. 
We believe that the five $\mathrm{C}$ theory is a novel approach to creativity and helps learn creativity better. The theory makes sense in our view and offer insights on corporate entrepreneurship, innovation and change which are requisite for competitive advantage in today's businesses. Whitehead's creativity as a process is relevant for changes and innovation in all entities. We need to provide more empirical evidence to validate these novel approaches.

\section{References}

Amabile, T. M. (1988). A model of creativity and innovation in organizations, Research in Organizational Behavior, 10, 123-167.

Argote, L. \& Miron-Spektor, E. (2011). Organizational learning: From experience to knowledge, Organizational Science, 22 (5), 1123-1137.

Boden, M. A. (1998). Creativity and artificial intelligence, Artificial Intelligence, 103 (1998), 347-356.

Bourdieu, P. (1977). Outline of a Theory of Practice (trans. by R. Nice), Cambridge, UK: Cambridge University Press.

Camazine, S. Deneubourg, J. Franks,N. Sneyd, J. Gheraulaz \& Bonabeau, E. (2003). Self-organization in biological systems, Princeton and Oxford: Princeton University Press.

Casson, M. (1998). An Entrepreneurial Theory of the Firm, Department of Economics, University of Reading, Reading, UK.

Casson, M. (2014). Entrepreneurship: A personal view, International Journal of the Economics of Business, 21(1), 7-12.

Catmull, E. (2008). How Pixar fosters collective creativity, Harvard Business Review, September 2008.

Coase, R. (1937). The nature of the firm, Economica, 4(16), 356-405.

Coleman, J.S. (1986). Social theory, social research, and a theory of action, American Journal of Sociology, 91(6), 1309-1335.

Csikszentmihalyi, M. (1996). Creativity: The Psychology of Discovery and Invention, New York: Harper Perennial Modern Classics.

Deleuze, G. (1994). Difference and Repetition, Trans. Paul Patton, New York: Columbia University Press.

Drucker, P. (1985). Innovation and Entrepreneurship, New York: Harper \& Row Publishers, Inc.

Fetz, R. L. (1990). Creativity: A new transcendental? Whitehead's Metaphysics of Creativity, F. Rapp and R. Wiehl (eds.), Albany: State University of New York Press, 189-208. 
Fischer, G. (2005). Creativity and distributed intelligence. http://www.cs.umd.edu/hcil/CST

Foss, N. (1999). Networks, capabilities, and competitive advantage, Scandinavian Journal of Management, 15 (1), 1-15.

Foss, N. J. \& Mahnke, V. (2000). Competence, Governance, and Entrepreneurship, Oxford University Press, Oxford, U.K.

Gibson, J. J. (1977). The theory of affordances, in Perceiving, Acting, and Knowing, Shaw \& J. Bransford, (eds.), Hillsdale, N.J.: Lawrence Erlbaum Associates.

Giddens, A. (1979). Central Problems in Social Theory, Berkeley: University of California Press.

Giddens, A. (1984). The Constitution of Society, Berkeley: University of California Press.

Glăveanu, V.P. (2012). Rewriting the language of creativity: The five A's framework, Review of General Psychology. Advance online publication. DOI: 10.1037/a0029528.

Glăveanu, V. P. (2014). Distributed Creativity: Thinking Outside the Box of the Creative Individuals, Heidelberg: Springer.

Griffin, D. R. (2007). Whitehead's Radically Different Postmodern Philosophy: An Argument for its Contemporary Relevance, Albany, NY: State University of New York Press.

Griffin, D. R. (1988). The Reenchantment of Science: Postmodern Proposal, Albany, NY: State University of New York Press.

Halewood, M. (2014). Rethinking the Social through Durkheim, Marx, Weber and Whitehead, New York: Anthem Press, 134-135.

Halewood, M. \& Michael, M. (2008). Being a sociologist and becoming a Whiteheadian: Toward a concrescent methodology, Theory, Culture \& Society, 25(4), 31-56.

Hartshorn, Charles \& Peden, Creighton (1981). Whitehead's view of reality, Newcastle, UK: Cambridge Scholars Publishing.

Heidegger, M. (1959). An Introduction to Metaphysics, New Haven: Yale University Press, 7-8.

Holcombe, R. G. (2003). The origin of entrepreneurial opportunities, The Review of Austrian Economics, 16(1), 25-43.

Isaacson, W. (2011). Steve Jobs, New York: Simon \& Schuster.

Kauffman, S. A. (1993). The Origin of order: Self-organization and selection in evolution, New York and Oxford: Oxford University Press.

Kirzner, I. M. (1997). Entrepreneurial discovery and the competitive market process: An Austrian Approach, Journal of Economic Literature, 35(1), 60-85. 
Kirzner, I. M. (1999). Creativity and/or alertness: A Reconsideration of Schumpeterian entrepreneur, Review of Austrian Economics,11, 5-17.

Kogut, B. \& Zander, U. (1992). Knowledge of the firm, combinative capabilities, and the replication of technology, Organization Science, 3 (3), 383-397.

Lehrer, J. (2012). Imagine How Creativity Works, Boston: Houghton Mifflin Harcourt.

Lombardo, B. J. \& Roddy, D. J. (2010). Cultivating organizational creativity in an age of complexity, Executive Report, New York: IBM Global Business Services.

Malvestiti, M. (2011). Plato's receptacle in the Timaeus: Towards a theory of matter, Working Paper, Department of Moral Philosophy, University of St. Andrews, St. Andrews, U.K.

Mesle, C.R. (2008). Process-Relational Philosophy, West Conshohocken, PA: Templeton Press.

Nonaka, I. (1994). A dynamic theory of organizational knowledge creation, Organization Science, 5(1), 14-37.

Nonaka, I., \& Takeuchi, H. (1995). The knowledge-creating company, Oxford, UK: Oxford University Press.

Park, H.Y., Reddy, S., Sarkar, S. (2000). Make or buy strategy of firms in the U.S. Multinational Business Review, 8 (2), 89-97.

Park, H. Y., Chang, H. \& Park, Y. (2015a). Firms' knowledge creation structure and new product development, Cogent Business \& Management, 2: 1023507.

Park, H. Y., Cho, I., Jung, S., \& Main, D. (2015b). Information technology and user knowledge-driven innovation in services, Cogent Business \& Management, 2: 1078869.

Park, H. Y., Misra, K., Reddy, S., \& Jaber, K. (2018). Family firms' innovation drivers and performance: A dynamic capabilities perspective, Journal of Family Business Management, 9 (1), pp.

Parashkevova, D. (2015). A conceptual history of the idea of self-causation: from Plato's forms to Hegel's concrete universal, Ph.D. thesis, National University of Ireland, Galway, http://hdl.handle.net/10379/5580

Popper, K. (1982). Of clocks and clouds. In H.C. Plotkin (ed), Learning, Development and Culture, New York: John Wiley \& Sons, Inc., 109-119.

Rose, C. (2014). Charlie Rose interview with Tim Cook (Apple CEO), PBS, September 14, 2014.

Rosenblum, M. J. (2016). A short In-depth philosophy of creativity: An Analysis of Whiteheadian Process Philosophy, eBook Kindle edition.

Rhodes, M. (1961). An analysis of creativity, Phi Delta Kappan, 42, 205-210.

Sawyer, R. K. \& DeZutter, S. (2009). Distributed creativity: How collective creations emerge from collaboration, Psychology of Aesthetics, Creativity, and the Arts, 3(2), 81-92. 
Schiuma, G. (2009). The managerial foundations of knowledge assets dynamics, Knowledge Management Research \& Practice, 7(4), 290-299.

Schumpeter, J. A. (1934). The Theory of Economic Development, New York: Oxford University Press. Shaviro, S. (2009). Without criteria: Kant, Whjitehead, Deleuze, and Aesthetics, Cambridge, MA: MIT Press

Soros, G. (2008). The new paradigm for financial markets: The credit crisis of 2008 and what it means. Philadelphia: Perseus Books Group.

Stengers, I. (2008). A constructivist reading of Process and Reality, Theory, Culture \& Society, 25(4), 91-110.

Stengers I. (2011). Thinking with Whitehead: A Free and Wild Creation of Concepts, Translated by Michael Chase, Cambridge, MA: Harvard University Press.

Twohill, L. (2012). The curious case of creativity, Think with Google: https://www.thinkwith google.com/articles/the-curious-case-of-creativity.html

Wallack, F. B. (1980). The Epochal Nature of Process in Whitehead's Metaphysics, Albany, NY: State University of New York Press.

Weber, M. (2016). Symbolism, its meaning and effect: The universal algebra of culture, The Journal of Natural and Social Philosophy, 12 (1), 350-377.

Weick, K. E. (ed.). (1977). Enactment Process in Organizations, Chicago: St. Clair Press.

Weick, K. E. (1979). The Social Psychology in Organizing, Reading, MA: Addison-Wesley.

Wieman (1946). The Source of Human Good, Southern Illinois University Press, London and Amsterdam: Feffer \& Simon, Inc.

Whitehead, A. N. (1927). Symbolism: Its meaning and effect, New York: Fordham University Press.

Whitehead, A. N. (1929/1978). Process and Reality, New York: Free Press.

Whitehead, A. N. (1933). Foresight, Chapter VI in the Adventures of Ideas, New York: The Free Press, 87-99.

Whitehead, A. N. (1938). Mode of thought, New York: Macmillan C0.

Whiteman, M. (2013). Collaboration to develop new business ideas, Dow Chemical Company, Midland, Michigan.

Williamson, O. E. (1975). Markets and Hierarchies: Analysis and Antitrust Implications, New York: Free Press.

Williamson, O. E. (1985). The Economic Institution of Capitalism, New York: Free Press. 
Williamson, O. E. (2008). Outsourcing: Transactions cost economics and supply chain management, 44(2), 5-16.

Young, J. G. (1985). What is creativity? Journal of Creative Behavior, 19(2), 77-87. 